\title{
Pelatihan Praktikum IPA SD Bagi Guru-Guru SD Yang Bukan Memiliki Latar Belakang IPA Di Kabupaten Bantul
}

\section{ES (Elementary School) Science Practicum Training For Teachers Who Do Not Have A Science Background In Bantul District}

\author{
R. Yosi Aprian Sari*, Denny Darmawan, Warsono, dan Ariswan \\ *Jurusan Pendidikan Fisika, FMIPA, UNY, email: ryosia@uny.ac.id
}

\begin{abstract}
Abstrak
Permasalahan pendidikan di Indonesia khususnya di Kabupaten Bantul salah satunya adalah kurang meratanya penyebaran guru khususnya pada keahlian tertentu, misalkan guru IPA. Di satu sisi, ada tuntutan keprofesional guru-guru artinya guru adalah faktor penentu keberhasilan proses pembelajaran yang berkualitas, sehingga berhasil tidaknya pendidikan mencapai tujuan selalu dihubungkan dengan kiprah para guru. Oleh karena itu, usaha-usaha yang dilakukan dalam meningkatkan mutu pendidikan hendaknya dimulai dari peningkatan kualitas guru.

Salah satu solusi terkait dengan permasalahan di atas, adalah memberikan pelatihan berupa praktikum IPA bagi guru SD yang tidak memiliki latar belakang IPA. Bentuk praktikum ini menyesuaikan dengan jenis percobaan yang ada di SD, yaitu sederhana dan bisa dilakukan oleh siswa sendiri.

Evaluasi yang dilakukan selama kegiatan PPM ini terdiri dari 2 bentuk, yaitu evaluasi kinerja yang dilakukan oleh tim PPM dan evaluasi berupa kuisioner yang diisi oleh peserta guru-guru. Dari evaluasi kinerja, peserta yang guru-gurunya mengikuti kegiatan pelatihan, rata-rata nilai aktivitasnya 83,3 masuk dalam kategori baik. Sedangkan dari kuisioner dapat disimpulkan, pelatihan sejenis sangat diperlukan untuk menambah pengalaman dan pengetahuan khususnya praktikum IPA.
\end{abstract}

Kata kunci: pelatihan praktikum IPA, proses pembelajaran IPA

One of the problems in education field in Indonesia, especially in Bantul, Yogyakarta, is the lack distribution of teachers particularly at certain skills, for example science teachers. On the contrary, there is a high demand of professional teachers which means that teachers become the factor of qualified learning process. The success or failure of education goals is always associated with the teachers' role. Therefore, the efforts made to improve the quality of education should start from improving the quality of teachers.

One of the solutions related to the above problem is to provide a science practicum training for elementary school teachers who do not have science background knowledge. This practical training adjusts to the types of experiment in elementary school which is simple and can be easily done by the students.

Evaluations carried out during the program consisted of two forms i.e. a performance evaluation conducted by the program team and an evaluation in the form of questionnaires filled out by the teachers. Based on the performance evaluation, teachers who participated in the training have successfully improved their ability. They obtained average value of 83.3 which represented good category. Meanwhile, based on the questionnaire, it can be concluded that similar training is necessary to deepen teachers' knowledge and give them experience especially in science practicum.

Keywords: science practicum training, teaching and learning process of science 


\section{PENDAHULUAN}

Ilmu Pengetahuan Alam (IPA) berkaitan dengan cara mencari tahu tentang alam secara sistematis, sehingga IPA bukan hanya penguasaan kumpulan pengetahuan saja tetapi juga merupakan proses penemuan. Pendidikan IPA diharapkan dapat menjadi wahana bagi siswa untuk mempelajari diri sendiri dan alam sekitar, serta prospek pengembangan lebih lanjut dalam menerapkannya didalam kehidupan sehari-hari.

Untuk mencapai tujuan pembelajaran IPA tersebut, penggunaan Laboratorium dalam pembelajaran sangat diharapkan. Laboratorium mempunyai fungsi yang sangat banyak, baik di bidang penelitian umum, pendidikan, dan lain-lain. Secara umum laboratorium berfungsi sebagai tempat untuk menguatkan / memberi kepastian keterangan (informasi), menentukan hubungan sebab-akibat (causalitas), membuktikan benar tidaknya faktor-faktor atau fenomena-fenomena tertentu, membuat hukum atau dalil dari suatu fenomena apabila sudah dibuktikan kebenarannya, mempraktekkan sesuatu yang diketahui, mengembangkan keterampilan, memberikan latihan, menggunakan metode ilmiah dalam memecahkan problem dan untuk melaksanakan penelitian perorangan (individual research).

Guru adalah faktor penentu keberhasilan proses pembelajaran yang berkualitas. Sehingga berhasil tidaknya pendidikan mencapai tujuan selalu dihubungkan dengan kiprah para guru. Oleh karena itu, usaha-usaha yang dilakukan dalam meningkatkan mutu pendidikan hendaknya dimulai dari peningkatan kualitas guru. Guru yang berkualitas diantaranya adalah mengetahui dan mengerti peran dan fungsinya dalam proses pembelajaran.

Karakteristik IPA menjadi sebuah dasar untuk menentukan sebuah pandangan yang baik bagi IPA khususnya anak IPA tetapi ini sudah menjawab IPA merupakan sebuah studi yang hanya mampu dilakukan sebagian orang dengan kata lain mempunyai stratifikasi khusus. Bagaimanakah anak yang tak mampu mempelajari IPA mengimbangi sebuah kehidupan yang akan mereka hadapi yaitu globalisasi yang menuntut bertahan pada pembelajaran holistik? Sesungguhnya mereka tidak pernah beruntung ke dunia ini.

Permasalahan lain yang timbul yaitu tidak adanya media pembelajaran yang memadai untuk menjelaskan suatu konsep diluar praktikumdan observasi. Hal ini akan mempersulit anak dalam memahami konsep sehingga tak jarang anak memahami diluar konsep yang sebetulnya jadi guru harus kreatif dan inovatif.

Berdasarkan hasil monitoring kelas pada saat pembelajaran IPA, banyak sekali masalah yang muncul yang dialami oleh guru, diantaranya :

1. Guru tidak siap mengajar, dalam arti terkadang guru belum memahami konsep materi yang diajarkan.

2. Kesulitan memahami pelajaran, guru sering kesulitan dalam memunculkan minat belajar anak.

3. Kurang optimal dalam penerapan metode pembelajran yang ada.

4. Kesulitan memilih dan menentukan alat peraga yang sesuai dengan materi yang diajarkan.

5. Kesulitan menanamkan konsep yang benar pada siswa dan sering bersifat verbalistik.

6. Bahkan yang sangat ironis, ada guru yang mengajar IPA tidak memiliki latar belakang IPA.

\section{SOLUSI/TEKNOLOGI}

Berdasarkan

permasalahanpermasalahan di atas diperoleh gambaran bahwa pelaksanaan kegiatan praktikum IPA SD membutuhkan perhatian yang lebih, terutama berkenaan dengan pengalaman guru dalam mengimplementasikan dalam bentuk percobaan IPA SD, yang diharapkan juga dapat memberi pemahaman, penyegaran sekaligus untuk menambah wawasan bagi guru-guru mengenai pelaksanaan praktikum IPA SD khususnya 
yang tidak memiliki latar belakang pendidikan IPA SD.

Langkah-langkah yang dilakukan dalam melaksanakan kegiatan ini adalah antara lain

(a) Tahap Persiapan

Pada tahap ini dipersiapkan semua alat dan bahan untuk tiap-tiap mata praktikum, baik dibawa oleh tim PPM maupun dari pihak guru-guru sendiri.

(b) Tahap Pelaksanaan

Pelaksanaan kegiatan PPM ini dilaksanakan di SDN Jetis, Bantul yang diikuti oleh 30 (tiga puluh) orang guru dari 40 orang guru yang diundang. Pelaksanaan kegiatan ini dilaksanakan dalam 8 (delapan) kali pertemuan, yaitu dengan materi praktikum

1. Ahad, 02-10-2016: Mekanika

2. Ahad, 09-10-2016: Kalor

3. Ahad, 16-10-2016 : Gelombang

4. Ahad, 23-10-2016 : Optik

5. Ahad, 30-10-2016 : Listrik Magnet

6. Ahad, 06-11-2016 : Bumi \& Alam Semesta

7. Ahad, 13-11-2016 : Balon Gas

8. Ahad, 20-11-2016 : Roket Air

Kegiatan no 7 dan 8 merupakan kegiatan selingan, yaitu pemanfaatan barang-barang bekas untuk media pembelajaran pada kegiatan sehari-hari.

(c) Tahap Evaluasi

Tahap evaluasi ini dilaksanakan pada bagian akhir pertemuan di tiap sesinya. Bentuk evaluasi ini diperoleh dari pengamatan dari Tim PPM maupun dari kuisioner yang diberikan.

\section{HASIL DAN DISKUSI}

Dari tiap tahap pelaksanaan kegiatan, dilakukan evaluasi kegiatan baik dilakukan oleh tim PPM maupun dari kuisioner, yaitu diperoleh

Tabel 1.Aktivitas Guru Selama Kegiatan Berlangsung

\begin{tabular}{|c|l|c|}
\hline No & Aspek Yang Dinilai & $\begin{array}{c}\text { Keberhasilan } \\
(\mathbf{\%})\end{array}$ \\
\hline 1. & Menyimak penjelasan & 85,0 \\
\hline 2. & $\begin{array}{l}\text { Melakukan percobaan } \\
\text { sesuai petunjuk }\end{array}$ & 90,0 \\
\hline
\end{tabular}

\begin{tabular}{|c|l|c|}
\hline 3. & $\begin{array}{l}\text { Hasil yang sesuai } \\
\text { dengan teori }\end{array}$ & 75,0 \\
\hline 4. & $\begin{array}{l}\text { Keinginan untuk } \\
\text { melakukan lagi }\end{array}$ & 85,0 \\
\hline 5. & $\begin{array}{l}\text { Keinginan melakukan } \\
\text { modifikasi }\end{array}$ & 80,0 \\
\hline 6. & $\begin{array}{l}\text { Dapat menjelaskan } \\
\text { hasil yang diperoleh }\end{array}$ & 85,0 \\
\hline \multicolumn{2}{|c|}{ Rata-Rata } & 83,3 \\
\hline
\end{tabular}

Tabel 2. Evaluasi Guru-Guru Selama Kegiatan Berlangsung

\begin{tabular}{|l|l|c|}
\hline No & Aspek Yang Dialami & $\begin{array}{c}\text { Pilihan } \\
\text { Ya (\%) }\end{array}$ \\
\hline 1. & $\begin{array}{l}\text { Keikutsertaan dalam } \\
\text { pelatihan IPA }\end{array}$ & 21,4 \\
\hline 2. & $\begin{array}{l}\text { Memahami pembelajaran } \\
\text { IPA }\end{array}$ & 7,1 \\
\hline 3. & $\begin{array}{l}\text { Menyusun perangkat } \\
\text { pembelajaran secara mandiri }\end{array}$ & 35,7 \\
\hline 4. & $\begin{array}{l}\text { Menyusun perangkat } \\
\text { pembelajaraan secara } \\
\text { berkelompok }\end{array}$ & 57,1 \\
\hline 5. & $\begin{array}{l}\text { Menyusun perangkat } \\
\text { pembelajaran dengan } \\
\text { menggunakan media yang } \\
\text { telah ada }\end{array}$ & 42,8 \\
\hline 6. & $\begin{array}{l}\text { Menyusun perangkat } \\
\text { pembelajaran dengan } \\
\text { menggunakan media yang } \\
\text { dibuat sendiri }\end{array}$ & 7,1 \\
\hline 7. & $\begin{array}{l}\text { Penerapan pendekatan } \\
\text { konstektual dalam } \\
\text { pembelajaran IPA }\end{array}$ & 64,3 \\
\hline 8. & $\begin{array}{l}\text { Penerapan pendekatan STM } \\
\text { dalam pembelajaran IPA }\end{array}$ & 35,7 \\
\hline 9. & $\begin{array}{l}\text { Sering melakukan percobaan } \\
\text { IPA }\end{array}$ & 64,3 \\
\hline 10. & $\begin{array}{l}\text { Merasa senang mengikuti } \\
\text { pelaksanaan pembelajaran } \\
\text { IPA }\end{array}$ & $\begin{array}{l}\text { Ada inovasi dalam } \\
\text { pembelajaran IPA }\end{array}$ \\
\hline 12. & $\begin{array}{l}\text { Pelatihan IPA masih } \\
\text { diperlukan }\end{array}$ \\
\hline
\end{tabular}

\section{KESIMPULAN}

Dari hasil kegiatan ini terlihat peserta yang guru-guru SD sangat antusias 
mengikuti kegiatan pelatihan ini dengan rata-rata nilai aktivitas 83,3 masuk dalam kategori baik. Sedangkan dari kuisioner yang diberikan oleh guru-guru, pelatihan sejenis sangat diperlukan untuk menambah pengalaman dan pengetahuan khususnya praktikum IPA.

\section{UCAPAN TERIMA KASIH}

Kegiatan PPM ini didanai oleh DIPA UNY dengan nomor kontrak : 1210/UN34.13/PM/2016, tanggal 1 Juni 2016.

\section{PUSTAKA}

Depdiknas. (2002). Pendekatan Kontekstual. Jakarta: Direktorat Pendidikan Dasar Dan Menengah

Marpaung M. "Memangnya Sains Itu Serius?

(http://netsains.Com/2008/04/Memangn ya-Sains-Itu-Serius

Nasution, S. (2003). Berbagai Pendekatan Dalam Proses Belajar Dan Mengajar. Jakarta: Bumi Aksara 